Journal of Finance Research

\title{
Analysis of the Impact of China's Novel Coronavirus Pneumonia on Chinese Enterprises' Performance
}

\section{Ying Zhao*}

Shandong Women's University, Jinan, Shandong, 250300, China

\begin{tabular}{l}
\hline ARTICLE INFO \\
\hline Article history \\
Received: 1 October 2020 \\
Revised: 6 October 2020 \\
Accepted: 9 October 2020 \\
Published Online: 16 October 2020 \\
\hline Keywords: \\
Epidemic situation \\
China \\
Enterprise performance \\
Impact
\end{tabular}

\section{Introduction}

$\mathrm{T}$ The novel coronavirus pneumonia, which was discovered by the Wuhan CDC in December 2019, is the most important public health event since the founding of the people's Republic of China, which has the fastest speed of transmission and the largest spread ${ }^{[1]}$. The state has taken a series of powerful measures to prevent and control the epidemic, such as blocking traffic, extending holidays and so on. With the joint efforts of the whole nation, the epidemic has been controlled, and the national production and living order has been gradually restored. Novel coronavirus pneumonia outbreak and prevention and control mainly concentrated in the first quarter of 2020. The series of measures adopted by the epidemic prevention have a great impact on the normal economic development. Based on the first quarter financial performance forecast released by listed companies, combined with some indicators reflecting macroeconomic

\section{ABSTRACT}

The outbreak of novel coronavirus pneumonia has affected almost all industries and enterprises. This paper analyzes the impact of the epidemic on the macro economy through GDP and other indicators, analyzes the impact of the epidemic on the overall business performance of the enterprises through the asset turnover speed index of the above scale industrial enterprises, and analyzes the impact of the epidemic on the net profit of the listed companies through the first quarter performance forecast of the listed companies. At last, the paper puts forward that enterprises should improve their awareness and ability to resist risks. indicators, the authors analyzed the impact of the new crown pneumonia epidemic on China's business performance.

\section{Analysis of Novel Coronavirus Pneumonia Epidemic Situation Impact on the Macro En- vironment}

On December 31, 2019, Wuhan health and Health Commission reminded the public to try to avoid going to public places where the air is not circulating and wear masks when going out; on January 23, 2020, the Ministry of transport informed Wuhan to close the airport, railway station and other channels, suspend the access to Wuhan road and waterway passenger transport lines, and do a good job in the health management of stations and other key places nationwide; on January 25, 2020, the Party Central Committee We began to promote local prevention and control work, strictly control traffic everywhere, and put into effect a series of

*Corresponding Author:

Ying Zhao,

2399 university road, Changqing district, Jinan city, Shandong province, 250300, China;

E-mail:31037@sdwu.edu.cn. 
measures, such as delaying the resumption of work by enterprises, delaying the opening of school, etc.; on February 23, 2020, the Party Central Committee proposed to restore the order of production and life in an orderly manner on the basis of grasping various epidemic prevention work ${ }^{[2]}$. According to the above timeline analysis, the impact of the epidemic on the external macro-economy of enterprises is mainly concentrated in January February 2020. Now, the GDP, production, consumption and investment indicators before and after the epidemic are summarized in Table 1.

Table 1. Comparison of macroeconomic indicators before and after the epidemic

\begin{tabular}{|c|c|c|c|c|c|c|c|}
\hline Year and month & $19.1-2$ & 19.3 & 19.4 & 19.5 & 19.6 & 19.7 & 19.8 \\
\hline GDP growth & $6.4 \%$ & $6.4 \%$ & $6.2 \%$ & $6.2 \%$ & $6.2 \%$ & $6 \%$ & $6 \%$ \\
\hline $\begin{array}{l}\text { Growth rate of in- } \\
\text { dustrial added value } \\
\text { above Designated } \\
\text { Size }\end{array}$ & $5.3 \%$ & $8.5 \%$ & $5.4 \%$ & $5 \%$ & $6.3 \%$ & $4.8 \%$ & $4.4 \%$ \\
\hline $\begin{array}{l}\text { Growth rate of total } \\
\text { retail sales }\end{array}$ & $8.2 \%$ & $8.7 \%$ & $7.2 \%$ & $8.6 \%$ & $9.8 \%$ & $7.6 \%$ & $7.5 \%$ \\
\hline $\begin{array}{l}\text { Growth rate of fixed } \\
\text { asset investment }\end{array}$ & $6.1 \%$ & $6.3 \%$ & $6.1 \%$ & $5.6 \%$ & $5.8 \%$ & $5.7 \%$ & $5.5 \%$ \\
\hline Year and month & 19.9 & 19.10 & 19.11 & 19.12 & $20.1-2$ & 20.3 & -- \\
\hline GDP growth & $6 \%$ & $6 \%$ & $6 \%$ & $6 \%$ & $-6.8 \%$ & $-6.8 \%$ & -- \\
\hline $\begin{array}{c}\text { Growth rate of added } \\
\text { value of industries } \\
\text { above Designated } \\
\text { Size } \\
\end{array}$ & $5.8 \%$ & $4.7 \%$ & $6.2 \%$ & $6.9 \%$ & $-13.5 \%$ & $-1.1 \%$ & -- \\
\hline $\begin{array}{c}\text { Growth rate of total } \\
\text { retail sales }\end{array}$ & $7.8 \%$ & $7.2 \%$ & $8 \%$ & $8 \%$ & $-20.5 \%$ & $-15.8 \%$ & -- \\
\hline $\begin{array}{l}\text { Growth rate of fixed } \\
\text { asset investment }\end{array}$ & $5.4 \%$ & $5.2 \%$ & $5.2 \%$ & $5.4 \%$ & $-24.5 \%$ & $-16.1 \%$ & -- \\
\hline
\end{tabular}

Note: Data from the National Bureau of Statistics of the People's Republic of China.

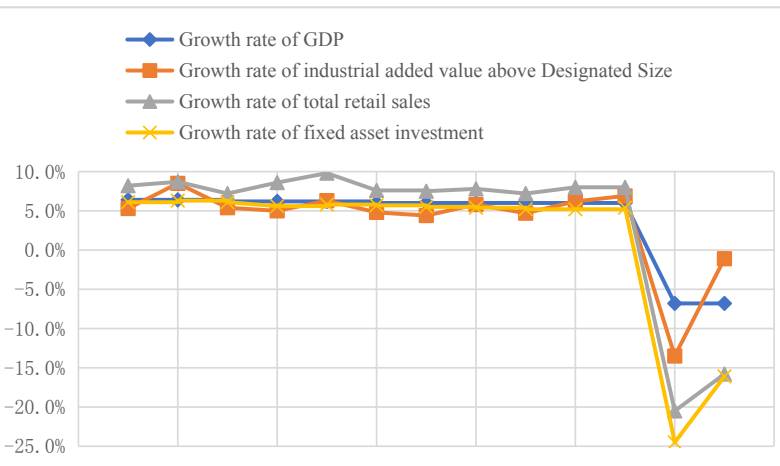

Figure 1. change trend of macroeconomic indicators before and after the epidemic

According to the data in Table 1 and the trend in Figure 1, before China novel coronavirus pneumonia outbreak, China's economic development was stable. The macroeconomic indicators showed a cliff breaking trend during the outbreak stage. The GDP and production, consumption and investment indicators fell sharply, especially fixed assets investment, which fell $24.5 \%$. This shows that the epidemic situation has a significant impact on the external macroeconomic environment of enterprises. ${ }^{[3]}$ After the epidemic was basically controlled at the end of February, the national policy changed from "comprehensive anti-epidemic" to "anti-epidemic + restart economy", and GDP, production, consumption, investment and other indicators began to rebound and rise, with a certain recovery ${ }^{[4]}$.

\section{Analysis of the Impact of Novel Coronavi- rus Pneumonia on Enterprise Performance}

\subsection{The Analysis of the Novel Coronavirus Pneu- monia Impact on the Overall Business Indicators of Enterprises}

The whole industrial chain operation of the enterprise will be affected by the strategies of blocking or strictly controlling the traffic and delaying the resumption of production. For example, the delay in the resumption of work by the enterprise itself will limit the production capacity and increase the labor cost; the delay in the resumption of work by upstream and downstream enterprises will delay the delivery of orders or products, or even fail to carry out normal operation; in addition, the traffic control will block the materials, which will greatly reduce the product turnover speed and payment collection speed of the enterprise ${ }^{[5]}$. Now, the indicators of accounts receivable and turnover period of finished products of Industrial Enterprises above Designated Size before and after the epidemic are summarized in Table 2.

Table 2. Comparison of overall business indicators of enterprises before and after the epidemic

\begin{tabular}{|c|c|c|c|c|c|}
\hline Year and quarter & Quarter & Quarter & Quarter & Quarter & Quarter \\
& 1,2019 & 2,2019 & 3,2019 & 4,2019 & 1,2020 \\
\hline $\begin{array}{c}\text { Receivables turnover } \\
\text { period of Industrial } \\
\text { Enterprises above } \\
\text { Designated Size }\end{array}$ & 55.2 days & 54.9 days & 54.7 days & 54.7 days & 71.3 days \\
\hline $\begin{array}{c}\text { Turnover period of } \\
\text { finished products of } \\
\text { Industrial Enterpris- } \\
\text { es above Designated } \\
\text { Size }\end{array}$ & 18.1 days & 17.6 days & 17.2 days & 17.3 days & 26.1 days \\
\hline
\end{tabular}

Note: the data is from data bank, which is calculated and collated.

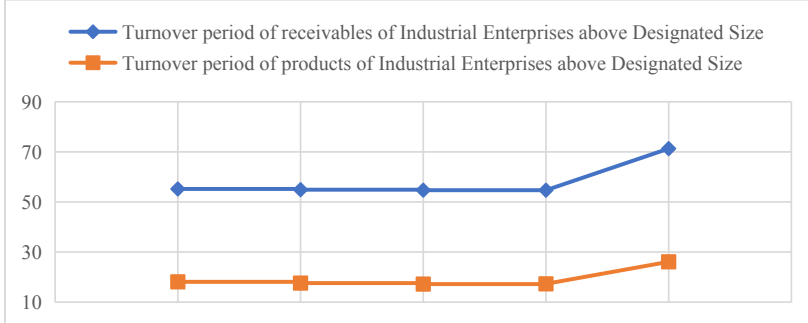

Figure 2. change trend of overall business indicators of enterprises before and after the epidemic 
According to the data in Table 2 and the trend in Figure 2 , before the outbreak of novel coronavirus pneumonia, the average receivable turnover period and finished product turnover period of Industrial Enterprises above designated size were relatively stable. Two indicators showed a sharp trend during the outbreak stage, especially the accounts receivable turnover period was extended by nearly $30 \%$. Traffic control and the delay of resumption of work in upstream and downstream enterprises will cause the following problems. First of all, there is no guarantee of sufficient supply of raw materials; second, employees do not return to work, and the production capacity is insufficient to produce enough products; finally, the market demand is insufficient, and the sales volume drops sharply, which will cause the company to extend the turnover period of finished products. In addition, the overall production and operation of the enterprise will need more cash flow support, but most enterprises will not hold a large amount of cash, which will affect the business credit between enterprises and greatly reduce the speed of payment collection ${ }^{[6]}$.

\subsection{Analysis of the Impact of Novel Coronavirus Pneumonia on the First Quarter Performance Forecast of Listed Companies}

At the end of March and the beginning of April, the listed companies successively published the performance forecast of the first quarter of 2020. Through multiple screening, the author selected ten companies with large changes in net profit, and sorted out the median of the company's predicted net profit and the median of the net profit year-on-year growth rate, as shown in Table 3. From the perspective of management, we can see the impact of the epidemic on Chinese enterprises ${ }^{[7]}$.

It can be seen from the data in the above table that the impact of the epidemic on Chinese enterprises is not so small. The above ten listed companies are all in profit in the first quarter of 2019. One epidemic directly turns profit into loss, and the loss range is huge. Among them, the first quarter loss of radio and television metering forecast is $90-130$ million yuan, with the largest amount of loss in advance. The decrease of the company's income and profit is mainly due to the delay in the resumption of work and production of the company and its customers during the epidemic period, traffic restrictions and other factors, resulting in the postponement of customer orders. Meanwhile, during the epidemic period, the cost of employee compensation, house rental, asset depreciation and other costs increased compared with the same period last year. With the novel coronavirus epidemic gradually controlled, the whole country has accelerated the resumption of pro- duction and resumption of production, and the company's business and orders have gradually returned to normal, and the company's market operation will continue to improve ${ }^{[8]}$. The above companies are all listed companies, with relatively strong anti-risk ability. The situation of unlisted SMEs should be more difficult.

Table 3. Statistics of the first quarter performance forecast of the listed companies with the largest impact of the epidemic in 2020

\begin{tabular}{|c|c|c|c|c|c|}
\hline Code & $\begin{array}{c}\text { Company } \\
\text { name }\end{array}$ & Industry & $\begin{array}{c}\text { Median fore- } \\
\text { cast net profit } \\
\text { for the first } \\
\text { quarter }\end{array}$ & $\begin{array}{l}\text { Com- } \\
\text { pared } \\
\text { with the } \\
\text { median }\end{array}$ & Reasons \\
\hline 002350 & CRERT & $\begin{array}{l}\text { Trans- } \\
\text { mission } \\
\text { electric }\end{array}$ & $\begin{array}{c}-4500 \mathrm{Ten} \\
\text { thousand } \\
\text { yuan }\end{array}$ & $-731 \%$ & $\begin{array}{l}\text { Delayed return } \\
\text { to work due to } \\
\text { epidemic }\end{array}$ \\
\hline 300011 & $\begin{array}{l}\text { DIN } \\
\text { HAN }\end{array}$ & $\begin{array}{c}\text { Delivery } \\
\text { equipment }\end{array}$ & $\begin{array}{c}-3450 \mathrm{Ten} \\
\text { thousand } \\
\text { yuan }\end{array}$ & $-564 \%$ & $\begin{array}{l}\text { The epidemic } \\
\text { led to a drop in } \\
\text { orders }\end{array}$ \\
\hline 300721 & $\begin{array}{c}\text { Yida } \\
\text { shares }\end{array}$ & $\begin{array}{l}\text { Chemical } \\
\text { industry }\end{array}$ & $\begin{array}{c}-1050 \text { Ten } \\
\text { thousand } \\
\text { yuan }\end{array}$ & $-549 \%$ & $\begin{array}{l}\text { The epidemic } \\
\text { makes it diffi- } \\
\text { cult to operate }\end{array}$ \\
\hline 300358 & \begin{tabular}{|c|} 
Truking \\
Technol- \\
ogy
\end{tabular} & $\begin{array}{l}\text { Medical } \\
\text { industry }\end{array}$ & $\begin{array}{c}-2550 \text { Ten } \\
\text { thousand } \\
\text { yuan }\end{array}$ & $-500 \%$ & $\begin{array}{l}\text { The epidemic } \\
\text { reduced income }\end{array}$ \\
\hline 300793 & $\begin{array}{c}\text { Jiahe in- } \\
\text { telligence }\end{array}$ & $\begin{array}{l}\text { Electronic } \\
\text { component }\end{array}$ & $\begin{array}{c}-740 \text { Ten } \\
\text { thousand } \\
\text { yuan }\end{array}$ & $-486 \%$ & $\begin{array}{l}\text { Delayed return } \\
\text { to work due to } \\
\text { epidemic }\end{array}$ \\
\hline 002658 & Sheraton & $\begin{array}{c}\text { Instruments } \\
\text { and Appa- } \\
\text { ratuses }\end{array}$ & $\begin{array}{c}-31.50 \mathrm{Ten} \\
\text { thousand } \\
\text { yuan }\end{array}$ & $-418 \%$ & $\begin{array}{c}\text { Delayed return } \\
\text { to work due to } \\
\text { epidemic }\end{array}$ \\
\hline 002922 & Igor & \begin{tabular}{|c|} 
Trans- \\
mission \\
electric \\
\end{tabular} & $\begin{array}{c}-480 \mathrm{Ten} \\
\text { thousand } \\
\text { yuan }\end{array}$ & $-348 \%$ & $\begin{array}{l}\text { The epidemic } \\
\text { reduced income }\end{array}$ \\
\hline 002364 & $\begin{array}{l}\text { Yueqing } \\
\text { City } \\
\text { Heng } \\
\text { Electric } \\
\end{array}$ & $\begin{array}{l}\text { Trans- } \\
\text { mission } \\
\text { electric }\end{array}$ & $\begin{array}{c}-2700 \text { Ten } \\
\text { thousand } \\
\text { yuan }\end{array}$ & $-337 \%$ & $\begin{array}{c}\text { Delayed return } \\
\text { to work due to } \\
\text { epidemic }\end{array}$ \\
\hline 002902 & Mentech & $\begin{array}{c}\text { Electronic } \\
\text { component }\end{array}$ & $\begin{array}{c}-1600 \text { Ten } \\
\text { thousand } \\
\text { yuan }\end{array}$ & $-271 \%$ & $\begin{array}{c}\text { Delayed return } \\
\text { to work due to } \\
\text { epidemic }\end{array}$ \\
\hline 002967 & \begin{tabular}{|c|} 
Radio \\
and \\
television \\
metering
\end{tabular} & $\begin{array}{l}\text { Compre- } \\
\text { hensive } \\
\text { industry }\end{array}$ & $\begin{array}{c}-11000 \text { Ten } \\
\text { thousand } \\
\text { yuan }\end{array}$ & $-237 \%$ & $\begin{array}{l}\text { Orders delayed } \\
\text { due to epidemic }\end{array}$ \\
\hline
\end{tabular}

Note: the data comes from the first quarter performance forecast of each company.

\section{Conclusion}

According to the previous analysis, a sudden outbreak of novel coronavirus pneumonia has a great negative impact on the external macroeconomic environment and the production and operation of enterprises. This is also a wake-up call to the operators of enterprises. Because the environment of enterprises is constantly changing, and even some disasters are beyond our reasonable expectation. Therefore, an enterprise must pay more attention to the operational risk and financial risk, do a good job in 
risk early warning and prevention and control mechanism, control the overall risk of the enterprise within the safe range, and be able to withstand the attack of external risk, so as to have the sustainability of development ${ }^{[9]}$.

\section{Reference}

[1] Wang Weiquan, Tao Dong. Regional emergency coordination mechanism and efficiency optimization in the context of new crown epidemic prevention and control $[\mathrm{J}]$. Journal of Shenzhen University (HUMANITIES AND SOCIAL SCIENCES EDITION),2020(2):117-123.

[2] Geng Hui, Xu Anding, Wang Xiaoyan, Zhang Yong, Yin Xiaomei, Ma Mao, Lu Jun. Based on SEIR model, the role of related interventions in the outbreak of new coronavirus pneumonia [J]. Journal of Jinan University (Natural Science and medicine), 2020 (2): 1-7.

[3] http://www.gov.cn/shuju/2020-04/18/con- tent 5503803.htm.

[4] Zhang Xianzhi. Reflections on the construction of China's Financial Analysis System J. Accounting Research. 20016:33-39.

[5] Li Wenjun, Li Xiaoxiang. A study on the relationship between emergency severity and firm performance -- An empirical analysis based on the regulation of redundant resources. Modern Management Science, 201111:55-57.

[6] Xiao Tusheng, Sun Ruiqi, Yuan Chun. Study on the preventive value of corporate cash holdings under the impact of new-crown pneumonia. Economic Management. 20204:179-191.

[7] https://new.qq.com/rain/a/20200329A0N87M00.

[8] http://quote.cfi.cn/zdsj/72861/002967.html.

[9] Richird D, Horan and Christonpher A, Wblf. The Economics of Managing Infectious Wildlife Disease[J]Amer. Afr. Econ, 2005(3):537-551. 